\title{
KERAGAMAN KONSEP KEPEMIMPINAN DALAM ORGANISASI
}

\author{
Hafulyon \\ Prodi Manajemen Pendidikan Islam STAIN Batusangkar \\ Jl. Sudiman No. 137 Kuburajo LimaKaum Batusangkar \\ e-mail: hafulyonyon@yahoo.com
}

\begin{abstract}
Quick effloresce leadership diversity along with changed it organization. Elements included leadership key as locomotive reach organization aim. For ala boss success conventional necessary approachings amongst those character approaching, behaviour and situasional. Meanwhile leadership in Islamic uses terminology umara orulil amri and khadimul ummah. That leadership diversity gets to be seen of severally variable inspire leadership amongst those autocratic, democratic, laissez faire That diversity its practice can at $\mathrm{k}$ ombinasikan in move subordinate in organisational, including confound that diversity is deep Islamic leadership concept via severally approaching amongst those keteladanan's approaching, integrity, and deliberation (democratic) to reach to the effect organization.
\end{abstract}

Key words: Keragaman, kepemimpinan, organisasi.

\section{PENDAHULUAN}

Kepemimpinan merupakan elemen yang sangat penting dalam sebuah organisasi, dibandingkan dengan elemen lainnya. Mengapa Kepemimpinan itu penting? karena manusia yang mengendalikan elemenelemen tersebut. Apabila kita telusuri peranan pemimpin yang berkaitan dengan organisasi adalah mengarahkan kerja yang strategis untuk mencapai tujuan organisasi, baik program jangka pendek, menengah dan jangka panjang. Kepeminpinan tentu saja sangat erat hubungannya dengan individu dan situasi dan iklim yang berada dalam suatu organisasi. Kepemimpinan yang efektifdalam organisasi diantaranya dapat mendorong, membangun, memberi bimbingan, nasehat, pelindung, teladan dan pengaruh terhadap individu dan kelompok yang berada dalam organisasi tersebut untuk mencapai tujuan organisasi yang telah ditetapkan sebelumnya.

Organisasi merupakan suatu wadah/ alat dalam aktivitas mencapai tujuan yang dilakukan melalui bauran konsep-konsep kepemimpinan, baik dalam arti organisasi secara umum atau mengacu bekerja sama untuk merealisasikan tujuan bersama.. Oleh karena itu Kepemimpinan adalah kemampuan mempengaruhi orang-orang untuk mencapai organisasional (Daft,2008:313), Sedangkan organisasi adalah sekelompok orang yang berinteraksi bekerja sama untuk merealisasikan tujuan bersama (Siswanto, 1990:74). Keragaman konsep kepemimpinan 
dalam organisasi disini maksudnya adalah mengintegrasikan atau pembauran konsepkonsep kepemimpinan yang sangat beragam berkaitan dengan interaksi dan kerjasama dalam mencapai tujuan pada suatu organisasi.

Tulisan ini akan memunculkan aneka ragam terhadap pembauran dari beberapa konsep-konsep kepemimpinan dalam organisasi. Berdasarkan hal tersebut penulis juga akan mengumukakan konsep-konsep kepemimpinan tersebut,juga dibaurkan dengan konsep kepemimpinan pendekatan Islam.

\section{PENGERTIAN KEPEMIMPINAN}

Pengertian kepemimpinan dalam tulisan ini akan dikemukakan oleh beberapa pendapat para ahli berikut ini :

A. Kepemimpinan dikemukakan oleh Ralph M. Stogdill dalam Wahjosumidjo 1994:22-24

1. Kepemimpinan sebagai suatu seni untuk menciptakan kesesuaian paham. (leadership as the art of inducing compliance). Ini berarti bahwa setiap pemimpin (leader) melalui kerja sama yang sebaik-baiknya harus mampu membuat para bawahan mencapai hasil yang telah ditetapkan.Peranan pemimpin memberikan dorongan terhadap bawahan untuk mengerjakan apa yang dikehendaki pemimpin.

2. Kepemimpinan sebagai suatu bentuk persuasi dan inspirasi (leadership as a form persuation). Kepemimpinan adalah suatu kemampuan mempengaruhi orang lain yang dilakukan bukan melalui paksaan melainkan himbauan dan persuasi.
3. Kepemimpinan adalah suatu kepribadian yang memiliki pengaruh (leadership as personality and its effects). Kepribadian dapat diartikan sebagai sifat-sifat (traits) dan watak yang dimilki oleh pemimpin yang menunjukkan keunggulan, sehingga menyebabkan pemimpin tersebut memiliki pengaruh terhadap bawahan.

4. Kepemimpinan adalah tindakan dan perilaku (leadership s act or behavior). Kepemimpinan dalam arti ini digambarkan sebagai serangkaian perilaku seseorang yang mengarahkan kegiatan-kegiatan bersama. Dari serangkaian perilaku tersebut dapat berupa menilai anggota kelompok, menentukan hubungan kerja sama, mampu memperhatikan kepentingan bawahan, dan sebagainya.

5. Kepemimpinan merupakan titik sentral proses kegiatan kelompok (leadership as a focus of proceses). Kepemimipinan sebagai titik sentral, sebab dalam kehidupan organisasi dari kepemimpinan diharapkan lahir berbagai gagasan baru, yang memberikan dorongan lahirnya perubahan., kegiatan dan seluruh proses kegiatan kelompok. Oleh karena itu, kepemimpinan tidak dapat dipisahkan daripada kehidupan kelompok dan menduduki posisi tinggi dalam kehidupan kelompok dalam menentukan struktur kelompok, suasana kelompok dan aktivitas kelompok. 
B. Kepemimpinan menurut Stephen P. Robbins adalah kemampuanuntuk mempengaruhi suatu kelompok untuk mencapai tujuan.(Robbins, 2002:163).

C. Kepemimpinan menurut Richard L Daft adalah : kemampuan mempengaruhi orang-orang untuk mencapai tujuan organisasional (Daft 2006:313).

D. Kepemimpinan G.R.Terry dan L.W.RVC adalah kemampuan mengarahkan pengikut-pengikutnya untuk bekerja bersama dengan kepercayaan serta tekun mengerjakan tugas-tugas yang diberikan pemimpin mereka. (Terry,2000:152).

E. Kepemimpinan pendekatanIslam antara lain ada 2 pengertian :

1. Umara atau Ulul Amri, maksudnya adalah orang yang mendapat amanah untuk mengurus urusan rakyat. Kalau dalam organisasi/perusahaan pemimpin tersebut mengurus kepentingan organisasi.

2. Khadimul Ummah menempatkan diri pada posisi sebagai pelayan masyarakat. Kalau dalam organisasi/ perusahaan harus berusaha berpikir cara-cara agar organisasi/ perusahaan yang dipimpinnya maju, karyawan sejahtera, serta masyarakat atau lingkungannya menikmati kehadiran organisasi/perusahaan. (Hafidhuddin, 2003:119-120).

Hal ini dipertegas dalam Al- Qur'an sebagai berikut:

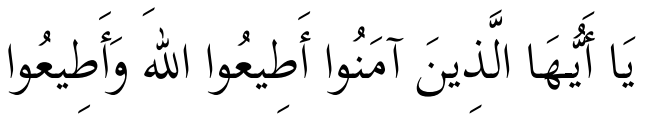

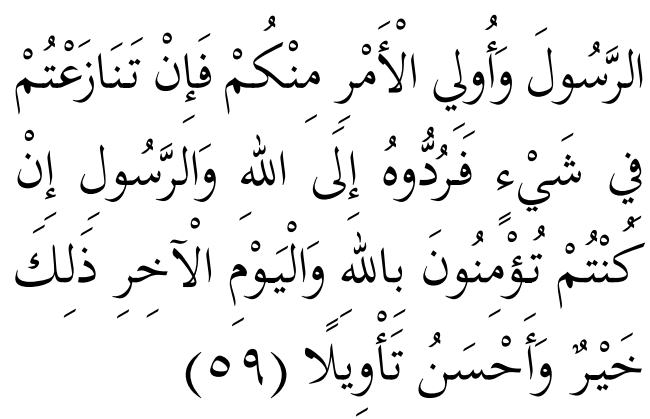

Artinya: Hai orang-orang yang beriman, taatilah Allah dan taatilah Rasul (nya), dan ulil amri di antara kamu. Kemudian jika kamu berlainan pendapat tentang sesuatu, Maka kembalikanlah ia kepada Allah (Al Quran) dan Rasul (sunnahnya), jika kamu benar-benar beriman kepada Allah dan hari kemudian. yang demikian itu lebih utama (bagimu) dan lebih baik akibatnya (QS.An Nisa: 59).

\section{LAHIRNYA KEPEMIMPINAN}

Penyebab lahirnya kepemimpinan sangat beragam, seperti membentuk diri sendiri yang disebut "self made man" yaitu kepemimpinan yang muncul karena kemampuan pada saatsaat yang penting atau situasi tertentu, dipilih oleh pengikut-pengikutnya, ditunjuk dari atas atau diangkat.Dengan kata lain, "headership" ditunjuk oleh "Board of Direction" untuk memimpin perusahaan atau diangkat oleh Dewan Komisaris, di antaranya juga ada tiga teori lain yaitu:

1. Teori Genetis (hereditytheory). Disebut "Leader are born not made", seseorang menjadi pemimpin karena dilahirkan dengan bakat-bakat kepemimpinan, Secara filosofis pandangan ini tergolong pada pandangan fatalis atau determinatis.

2. Teori Sosial, ini teori ekstrim inti ajarannya, Leader are made and not born". Jadi berlawanan dengan terori 
genetis, bahwa setiap orang bisa jadi pemimpin bila diberikan pendidikan dan pengalaman yang cukup.

3. Teori Ekologis, sebagai reaksi kedua hal itu bahwa: seseorang hanya berhasil menjadi pemimpin yang baik bila ia pada waktu kelahirannya memiliki bakat-bakat kepemimpinan, bakat-bakat itu kemudian dikembangkan melalui pendidikan yang teratur dan pengalaman-pengalaman, yang memungkinkan untuk mengembangkan lebih lanjut bakat-bakat yang dimilikinya (Herujito, 2001:200).

Dari beberapa pengertian kepemimpinan di atas dapat ditarik simpulan, bahwa kepemimpinan itu akan muncul dalam situasi dan kondisi tertentu individu mempengaruhi perilaku orang lain, baik secara individu maupun kelompok, sedangkan kalau ditinjau dari perspektif Islam adalah mengurus dan melayani orang lain,bawahan masyarakat, agar maju, berkembang dan sejahtera.

\section{PENGERTIAN ORGANISASI}

Pengertian organisasi akan dikemukakan menurut pendapat ahli sebagai berikut ini:

A. Pengertian organisasi dikemukakan olehDalas S Beach dalam Burhanuddin, adalah: suatu sistem, mempunyai struktur dan perencanaan yang dilakukan dengan penuh kesadaran, di dalamnya orangorang bekerja dan berhubungan satu sama lain dengan suatu cara yang terkoordinasi dan kooperatif guna mencapai tujuantujuan yang telah ditetapkan (Burhanudin 1994:192).
B. Pengertian organisasi menurut Bedjo Siswanto adalah: sekelompok orang yang saling berinteraksi dan bekerja sama untuk merealisasikan tujuan bersama (Siswanto, 1990:74)

C. Pengertian organisasi menurut Didin Hafidhuddin, yaitu pertama, organisasi sebagai wadah atau tempat, dan kedua, pengertian organisasi sebagai proses yang dilakukan bersama-sama, dengan landasan yang sama, dan juga dengan cara-cara yang sama (Hafidhuddin,2003:27).

\section{PROSES PENGORGANISASIAN}

Proses pengorganisasian multi langkah, (Dale dalam Sabardi,2001:86-87) adalah:

\section{Pemerincian Pekerjaan}

Memerinci seluruh pekerjaan yang harus dilaksanakan untuk mencapai tujuan organisasi. Setiap organisasi dibentuk dengan seperangkat tujuan: misalnya rumah-rumah sakit diadakan untuk merawat orang sakit, perusahaan dibentuk untuk menghasilkan barang dan jasa, tim sepak bola dibentuk untuk memenangkan pertandingan. Pencapaian tiap tujuan jelas sekali dilakukan dengan cara yang berbeda-beda. Oleh karena itu, untuk mencapai tujuan organisasi, pertamatama harus ditentukan tugas organisasi secara keseluruhan. Sebagai contoh, sebelum organisasi rumah sakit dapat membantu orang yang sakit, mereka harus membeli peralatan, memperkerjakan dokter dan pegawai profesional dan non profesional lainnya, membentuk berbagai departemen medis khusus, mengatur adanya pengakuan dari 
organisasi-organisasi profesional, koordinasi dengan berbagai lembaga kemasyarakatan $\mathrm{dsb}$.

\section{Pembagian Pekerjaan}

Membagi beban kerja kedalam aktivitasaktivitas yang secara logis dan menyenangkan apat dilakukan oleh seseorang atau oleh sekelompok orang. Organisasi dibentuk karena pekerjaan yang akan diselesaikan tidak dapat dilakukan oleh satu orang saja. Dengan demikian, pekerjaan organisasi haruslah dibagi secara tepat di antara anggotanya. Istilah tepat berarti: (a) Pertama dimaksukan bahwa setiap orang akan diberikan tugas atas dasar kualifikasinya atau tugas tersebut dan (b) kedua, bahwa tidak seorangpun yang akan ditugas untuk melaksanakan beban kerja yang terlalu berat atau terlalu ringan.

\section{Pemisahan Pekerjaan (Pen- departemenan)}

Pada suatu perusahaan memperbesar ukurannya dan mengangkat pegawai lebih banyak untuk melakukan berbagai aktivitas, maka pekerjaan masing-masing kelompok anggota perlu dikaitakan/dipadukan. Departemen-departemen yang umum dijumpai dalam perusahaan manufaktur adalah:
a. Penjualan
b. Produksi
c. Akuntansi
d. Personalia
e. Pemasaran

Dalam departemen tertentu terdapat karyawan-karyawan yang memiliki sejumlah keterampilan dan tingkat keahlian yang berda-beda, di mana interaksi antar mereka diatur dengan prosedur yang sudah ditetapkan. Pemisahan pekerjaan seperti itu pada umumnya disebut sebagai departemen.

\section{Koordinasi Pekerjaan}

Penepatan mekanisme untuk mengkoordinasi pekerjaan anggota organisasi satu kesatuan yang harmonis. Contoh, manajer pemasaran dalam suatu perusahaan manufaktur bole jadi mendesak adanya anggaran periklanan yang lebih besar untuk memacu atau menarik permintaan sedangkan perusahaan lebih menaruh perhatian pada penanaman modal dalam peralatan otomatis untuk memperkecil pengeluaran biaya produksi.

\section{Monitoring dan reorganisasi}

Memonitor efektifitas organisasi dan pengambilan langkah-langkah penyesuaian untuk mempertahankan atau meningkatka efektifitas. Karena pengorganisasian merupakan suatu proses yang berkelanjutan, maka diperlukan adanya penilaian ulang terhadapa keempat langkah sebelumnya secara berkala.

Tidak ada cara terbaik untuk merancang struktur yang dapat diterapkan bagi semua oarganisasi. Struktur yang paling diinginkan berbeda-beda, bergantung pada masing-masing organisasi dan dalam organisasi sekalipun struktur itu akan berbada dari waktu ke waktu.

\section{KERAGAMAN KEPEMIMPINAN DALAM ORGANISASI}

Keragaman konsep kepemimpinan dalam organisasi pada pembahasan ini, penulis membatasi melalui pendekatan konsep 
kepemimpinan secara konvensional dan kepemimpinan melalui pendekatan Islam.

\section{A. Pendekatan konsep kepemimpinan secara konvensional}

Ada tiga pendekatan terhadap telaah kepemimpinan antara lain yaitu pendekatan sifat-sifat, perilaku dan situsional atau "Contingency"di dalam telaah kepemimpinan.

1. Teori sifat kepemimpinan

Teori sifat pemimpin (Traits theory). Pada tahun 1910, Thomas Carlyle mengemukakan "teori yang besar" tentang kepemimpinan itu menetapkan bahwa kemajuan dunia adalah buah hasil karya dari orang-orang besar.Meskipun beberapa penelitian menyarankan pentingnya sifat-sifat pemimpin, tetapi penelitiannpenelitian lainnya menyatakan sulit untuk mengidentifikasi sifat-sifat kepemimpinan yang dapat digunakan terus sebagai standar untuk mengukur individu-individu baik sebagai pemimpin maupun bukan.

2. Pendekatan Perilaku (Gaya dan tipe-tipe Kepemimpinan)

Pemimpin menggunakan kekuasaanya, ada tiga tipe dasar, adalah authocratic, democratic atau participative, dan free rein atau laissez faire,(Koontz, 1984:509):

a Gaya kepemimpinan otoriter (autocratic)

Pemimpin yang bertipe demikian dipandang sebagai orang yang memberikan perintah dan mengharapkan pelaksanaannya secara dogmatis dan selalu positif. Dengan segala kemampuannya, ia berusaha menakut-nakuti bawahannya dengan jalan memberikan hukuman tertentu bagi yang berbuat negatif.

b. Gayakepemimpinan demokratis (Democratic)

Pemimpin yang bertipe demikian mengadakan konsultasi dengan para bawahannya mengenai tindakantindakan dan keputusan-keputusan yang diusulkan/dikendaki oleh pimpinan, serta berusaha memberikan dorongan untuk turut serta aktif melaksanakan semua keputusan dan kegiatan-kegiatan yang telah ditetapkan.

c. Gaya kepemimpinan bebas (LaissezFaire)

Pemimpin hanya berpartisipasi minimum, para bawahannya menentukan sendiri tujuan yang akan dicapai dan menyelesaikan sendiri masalahnya.

3. Pendekatan situsional atau "Contingency" Pendekatan situsional atau "Contingency adalah model kepemimpinan yang mendeskripsikan hubungan antara gaya kepemimpinan dan situasi-situasi organisasional tertentu. (Daft.L, 2006 : 325-326). Pendekatan ini menjelaskan para pemimpin perlu menyesuaikan gaya kepemimpinan mereka sebagai respon terhadap berbagai karakter dari orangorang yang menjadi bawahannya, seperti: harapan kerja, pengalaman, keahlian dan kesanggupan dalam menerima tanggung jawab. 


\section{B. Konsep Kepemimpinan Pendekatan Islam.}

Kepemimpinan pendekatan Islam sangat banyak ragamnya antara lain adalah:

\section{Pendekatan Keteladanan}

Modelkepemimpinan yang ideal dalam Islam diantaranya adalah meniru/ merujuk/berpedoman kepada model kepemimpinan Rasulullah SAW, yaitu ketepatan sistem, metode dalam berdiskusi, sebagaimana dibuktikan dalam Surat An Nahl berikut ini :

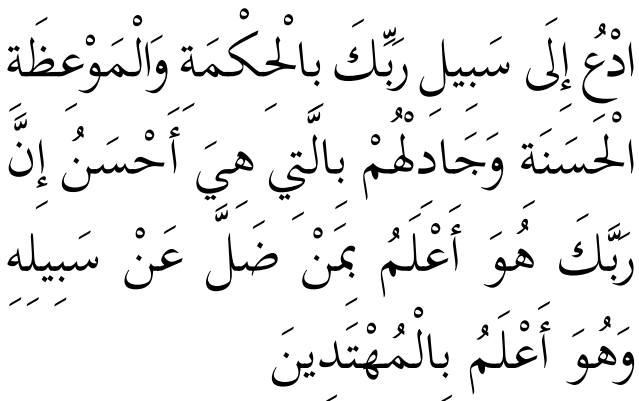

Serulah (manusia) kepada jalan Tuhan-mu dengan hikmah dan pelajaran yang baik dan bantahlah mereka dengan cara yang baik. Sesungguhnya Tuhanmu dialah yang lebih mengetahui tentang siapa yang tersesat dari jalan-Nya dan dialah yang lebih mengetahui orang-orang yang mendapat petunjuk. (QS 16:125).

Kepemimpinan Rasul ini penuh dengan kebijaksanaan dan berdiskusi dengan bawahan dengan metode yang baik, pendelegasian wewenang, bertipe kharismatik dan demokratis. Keteladanan Nabi Muhammad SAW sesuai dengan ayat berikut:

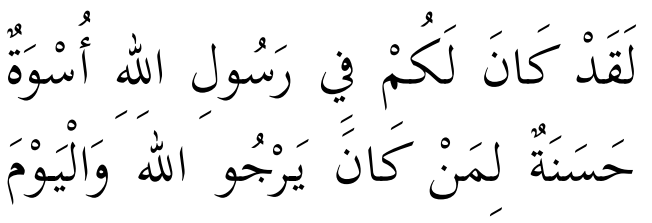

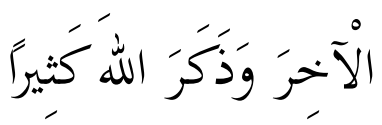

Sesungguhnya Telah ada pada (diri) Rasulullah itu suri teladan yang baik bagimu (yaitu) bagi orang yang mengharap (rahmat) Allah dan (kedatangan) hari kiamat dan dia banyak menyebut Allah. (QS 33:21).

Bertitik tolak dari keteladanan Nabi Muhammad SAW diantaranya ialah kepribadian yang tannguh dan prinsip yang kokoh dan kuat.

\section{Pendekatan Integritas}

Pendekatan integritas adalah suatu yang memperoleh kepercayaan. Integritas, komitmen dan konsisten dalam memimpin dibuktikan dengan perilaku dalam organisasi, yaitu kesesuaian antara ucapan dan tindakan untuk membangun kepercayaan, sebagaimana yang tertuang dalam ayat berikut ini:

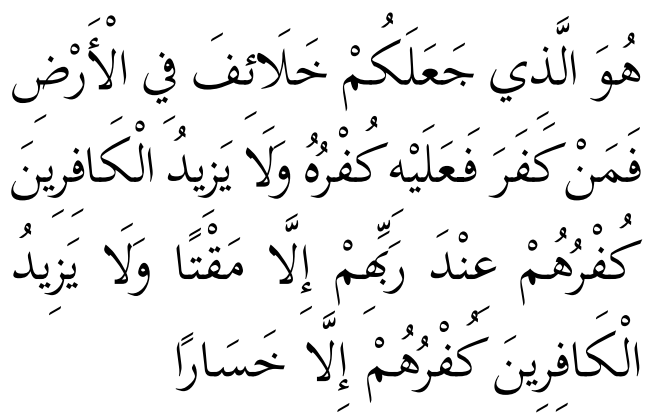

Artinya: Dia-lah yang menjadikan kamu khalifah-khalifah di muka bumi. barangsiapa yang kafir, Maka (akibat) kekafirannya menimpa dirinya sendiri. dan kekafiran orang-orang yang kafir itu tidak lain hanyalah akan menambah kemurkaan pada sisi Tuhannya dan kekafiran orangorang yang kafir itu tidak lain hanyalah akan menambah kerugian mereka belaka. (QS 35:39).

Kepemimpinan yang memiliki integritas yang tinggi adalah orang dengan

Keragaman Konsep Kepemimpinan dalam Organisasi 
penuh keberanian serta berusaha tanpa kenal putus asa untuk dapat mencapai apa yang ia cita-citakan.Integritas akan membuat dipercaya, dan kepercayaan itu akan menciptakan pengikut. Dan kemudia tercipta sebuah kelompok yang memiliki kesamaan tujuan (Agustian 2008:152).

Pemimpin wajib mempunyai integritas tinggi otomatis kejujurannya dan kepercayaannya teruji dalam kewajiban melaksanakan tugas, sebagaimana ditegaskan dalam ayat berikut:

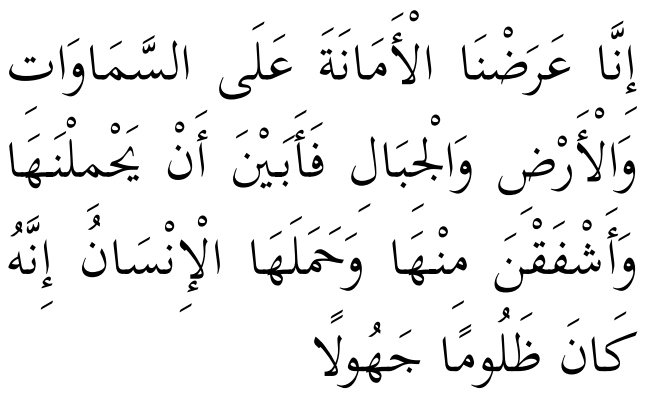

Sesungguhnya kami Telah mengemukakan amanat kepada langit, bumi dan gununggunung, Maka semuanya enggan untuk memikul amanat itu dan mereka khawatir akan mengkhianatinya, dan dipikullah amanat itu oleh manusia. Sesungguhnya manusia itu amat zalim dan amat bodoh. (QS 33:72).

Amanah tersebut dapat digambarkan diantaranya melalui amanah moral, yang berarti bukan hanya masalah materi saja, tetapi juga non-materi. Termasuk ketuntasan pekerjaan yang telah ditugaskan untuk mencapai tujuan yang sempurna, dan tidak mengeksploitasi bawahan untuk kepentingan individu, kelompok juga menghilangkan hakhak bawahan. Untuk itu perlu standar kepemimpinan sebagaimana ditegaskan ayat berikut ini :

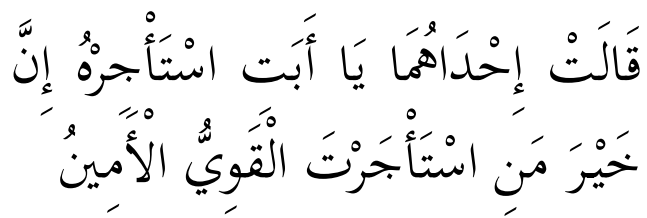

Salah seorang dari kedua wanita itu berkata: "Ya bapakku ambillah ia sebagai orangyang bekerja (pada kita), Karena Sesungguhnya orang yang paling baik yang kamu ambil untuk bekerja (pada kita) ialah orang yang Kuat lagi dapat dipercaya. (QS 28:26 ).

\section{Pendekatan Musyawarah(demokratis)}

Pemimpin yang sukses adalah yang mampu bermusayawarah dengan bawahannya dalam melakukan pelaksanaan proses berorganisasi. sebagaimana ditegaskan ayat berikut ini:
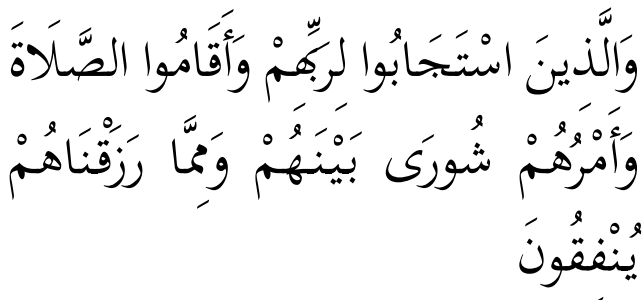

Dan (bagi) orang-orang yang menerima (mematuhi) seruan Tuhannya dan mendirikan shalat, sedang urusan mereka (diputuskan) dengan musyawarat antara mereka; dan mereka menafkahkan sebagian dari rezki yang kami berikan kepada mereka. (QS 42:38).

Hal ini dicontohkan oleh Nabi Muhammad SAW, bahwa beliau sebenarnya mampu membuat keputusan sendiri, namun melalui musyawarah dapat membangun persaudaraan dan melibatkan bawahan untuk mengambil keputusan dan pemecahan masalah bersama dalam organisasi.Dari konsep-konsep kepemimpinan perspektiffslam tersebut di atas 
terbangun kepemimpinan yang sejati yaitu seseorang yang selalu mencintai dan memberi perhatian kepada orang lain, sehingga ia dicintai, Memiliki integritas yang kuat, sehingga dipercaya oleh pengikutnya. Selalu membimbing dan mengajari pengikutnya. Memiliki kepribadian yang kuat dan konsisten. Dan yang terpenting adalah memimpin berlandaskan hati yang fitrah (Agustian,2001:167).

\section{PENUTUP}

Berdasarkan pembahasan yang berkaitan dengan keragaman konsep kepemimpinan dalam organisasi dapat disimpulkan sebagai berikut :

1. Dari beberapa pengertian kepemimpinan di atas dapat ditarik simpulan, bahwa kepemimpinan itu akan muncul dalam situasi dan kondisi tertentu. Individu dapat mempengaruhi perilaku orang lain, baik secara individu maupun kelompok.

2. Keragaman konsep kepemimpinan secara konvensional melalui pendekatan teori sifat, teori perilaku dan situasional dalam organisasi, maksudnya kepemimpinan sering berbeda-beda dari kondisi dan situasi yang beragam.

3. Kepemimpinan dalam Islam sangat normatf yang berasaskan kepada Al Quran dan As- Sunnah. Konsep kepemimpinan pendekatan Islam yang penulis bahas hanya melalui pendekatan keteladanan,integritas, komitmen, konsisten dan bermusyawarah terhadap beawahan yang dipimpinnya hal ini dikarenakan pemimpin sebagai fokus penggerak lokomotif dalam organisasi.

\section{KEPUSTAKAAN ACUAN}

Agustian Ary Ginanjar,Emotional SpiritualQuotient, Jakarta:ARGA Publising, 2008.

Daft Richard L, Manajemen, Jakarta: Salemba Empat, 2006.

Gary, Dessler, Manajemen Sumber Daya Manusia, Jakarta: PT Peherlindo, 1999.

GR. Terry dan L.W, RVC, Dasar-dasar Manajemen, Jakarta: Bumi Aksara, 2000. , Prinsip-prinsip Manajemen, Jakarta: Bumi Aksara, 2000.

Kontz Harold, Principles Of Management Of Managerial Function, Third Edition, New York: Mc. Graw-Hill Book Company, 1964.

Robbin Stephen, P, Perilaku Organisasi, Jilid 1 dan 2 Alih Bahasa: Tim Indeks Kelompok Gramedia, 2003

Siagian, Sondang, P, Manajemen Sumber Daya Manusia, Jakarta: Bumi Aksara, 2002. , Manajamen Stratejik, Jakarta: Bumi Aksara, 2000.

Sabardi Agus, Manajemen Pengantar, Yogyakarta: UPP AMP YKPN, 2001.

Siswanti Bedjo, Manajemen Modern Konsep dan Aplikasi, Bandung: Sinar Baru, Cetakan pertama, 1990.

Stoner James A, Management, Third Edition,New Jersey: Pretice Hall, 1986.

Sugono Dendy, Kamus Besar Bahasa Indonesia, Jakarta: Pusat Bahasa Gramedia, 2008. 
Tisnawati Ernie Sule, Pengantar Manajemen, Wahyosumidjo, Kepemimpinan dan Motivasi, Jakarta: Kencana, 2006. Jakarta: Ghalia Indonesia, 1984. 